\title{
O precyzji sondowania statycznego na przykładzie badań gruntów przejściowych poletka badawczego AMU Morasko
}

\author{
Jędrzej Wierzbicki ${ }^{1}$, Zbigniew Młynarek ${ }^{2}$, Waldemar Wołyński ${ }^{3}$
}

On the quality of CPTU results in terms of precision; a case of soft intermediate soils, AMU Morasko test site. Prz. Geol., 68: 655-662; doi: 10.7306/2020.25

\begin{abstract}
A b s tra ct. The Cone Penetration Test is one of the most versatile and widely used geotechnical tests over the world. Some differences in technical solutions between the equipment manufactured by different producers and the relatively quick wear of the penetrometer itself make the issue of quality and comparability of the CPTU results very actual. The tests were conducted in the testing ground of Adam Mickiewicz University in Poznań. The test site is located in the northern part of Poznań, within a marginal zone of the Poznan Phase of the Weichselian (Vistulian) glaciation. The subsoil consists of glacial till of the Riss glaciation and glacial till of the Vistulian glaciation, separated by fluvioglacial sandy sediments and covered with fine and medium sands with single gravel grains. The quality of geotechnical parameters of the tested subsoil was assessed for the initial constrained modulus and undrained shear strength. To determine these parameters, static penetrometers produced by two different manufacturers were used. The tests and the results of analysis were performed in three stages. In the first stage, each penetrometer was used to investigate homogeneity and diversity of the subsoil structure in the test sites. The subsoil structure diversity was examined by grouping statistically similar $R_{f}$ coefficient values along the profile. In the second stage, the level of accuracy and precision in the assessment of the corrected cone resistance - $q$, friction on the friction sleeve $-f_{s}$, and pore pressure - $u_{2}$ was determined for individual penetrometers. In the next stage, the differences between the constrained modulus and undrained shear strength were determined for both penetrometers. This analysis takes into account the level of precision of the corrected cone resistance.
\end{abstract}

Keywords: CPTU quality, intermediate soils, compressibility, strength

Sondowania statyczne CPTU (Cone Penetration Test with Pore Pressure Measurement) sa powszechnie wykorzystywane do wyznaczania parametrów geotechnicznych gruntu w warunkach in situ. Zróżnicowanie sprzętu do tych badań, wynikające zarówno z odmiennych rozwiązań technicznych stosowanych przez producentów, jak i względnie szybkiego zużywania się poszczególnych elementów pomiarowych, na ważnym miejscu stawia kwestię precyzji tych badań i porównywalności wyników. W badaniach geologiczno-inżynierskich wykorzystywanych do projektowania inwestycji niezwykle istotne znaczenie ma jakość wyznaczonych parametrów, szczególnie mechanicznych. O precyzji badania gruntu in situ, w tym CPTU, decyduja dwa czynniki. Pierwszym jest niejednorodność podłoża, zależna od zmian struktury i uziarnienia gruntu, natomiast drugim niepewność pomiarowa, związana z budową penetrometru i wykonaniem badania (Lumb, 1974; Młynarek, 2010). Lacasse i Nadim (1994) stwierdzili, że wpływu obu czynników na rejestrowane parametry w badaniu in situ nie można rozdzielić. Częściowo kwestię niepewności wyników pomiarów zależnych od budowy penetrometru uwzględniono w instrukcji Technical Commitee TC-16 (obecnie TC-102) ISSMGE For Cone Penetration Test CPTU and CPT (1999) oraz w normie ISO 22476-1 (2012), wprowadzając klasy penetrometrów. Wyniki badań wykonanych przez Norwegian Geotechnical Institute na poletku doświadczalnym Onsoy, gdzie w podłożu występuje niemal trzydziestometrowa warstwa miękkoplastycznego iłu (Lunne i in., 2003) wskazuja, że nawet w tak jednorodnym genetycznie i litologicznie podłożu parametry sondowania: opór stożka $\left(q_{c}\right)$, tarcie na pobocznicy $\left(f_{s}\right)$ i wzbudzone ciśnienie porowe $\left(u_{2}\right)$, rejestrowane przez różne penetrometry, mogą różnić się w sposób statystycznie istotny (Młynarek i in., 2002). Można się zatem spodziewać, że w podłożu składającym się z gruntów przejściowych, w którym warunki odpływu są bardziej złożone, problem ten będzie silniej wyeksponowany. Analiza tego zagadnienia stanowi cel niniejszego artykułu.

\section{OBSZAR I PROGRAM BADAŃ}

Badania wykonano na obszarze poletka badawczego AMU Morasko, w jego południowej części (ryc. 1). Poletko to jest zlokalizowane na terenie kampusu Uniwersytetu im. Adama Mickiewicza w Poznaniu, blisko północnych granic miasta, w sasiedztwie Rezerwatu Meteoryt Morasko (Radaszewski, Wierzbicki, 2019).

Powierzchnia terenu objętego badaniami została uformowana przez procesy lodowcowe i wodnolodowcowe zlodowacenia wisły (Stankowski, 2008). Miąższość osadów czwartorzędowych osiaga w tym miejscu ok. $40 \mathrm{~m}$. Sa one reprezentowane przez gliny lodowcowe zlodowaceń odry, warty oraz wisły. Kompleks tych osadów jest przykryty warstwą piasków drobnych i średnich z domieszkami żwiru, stanowiących pozostałość po sandrze uformowanym u schyłku fazy poznańskiej ostatniego zlodowacenia.

Profil geologiczny miejsca badań $\mathrm{z}$ naniesionymi wynikami analizowanych sondowań CPTU przedstawiono na ryc. 2. Ze względów geotechnicznych najbardziej interesującą częścią tego profilu jest vistuliańska glina

\footnotetext{
${ }^{1}$ Instytut Geologii, Wydział Nauk Geograficznych i Geologicznych, Uniwersytet im. Adama Mickiewicza w Poznaniu, ul. Bogumiła Krygowskiego 12,60-680 Poznań; jwi@amu.edu.pl

Uniwersytet Przyrodniczy w Poznaniu, ul. Wojska Polskiego 28, 60-637 Poznań

${ }^{3}$ Wydział Matematyki i Informatyki, Uniwersytet im. Adama Mickiewicza w Poznaniu, ul. Umultowska 87, 61-614 Poznań; wolynski@amu.edu.pl
} 


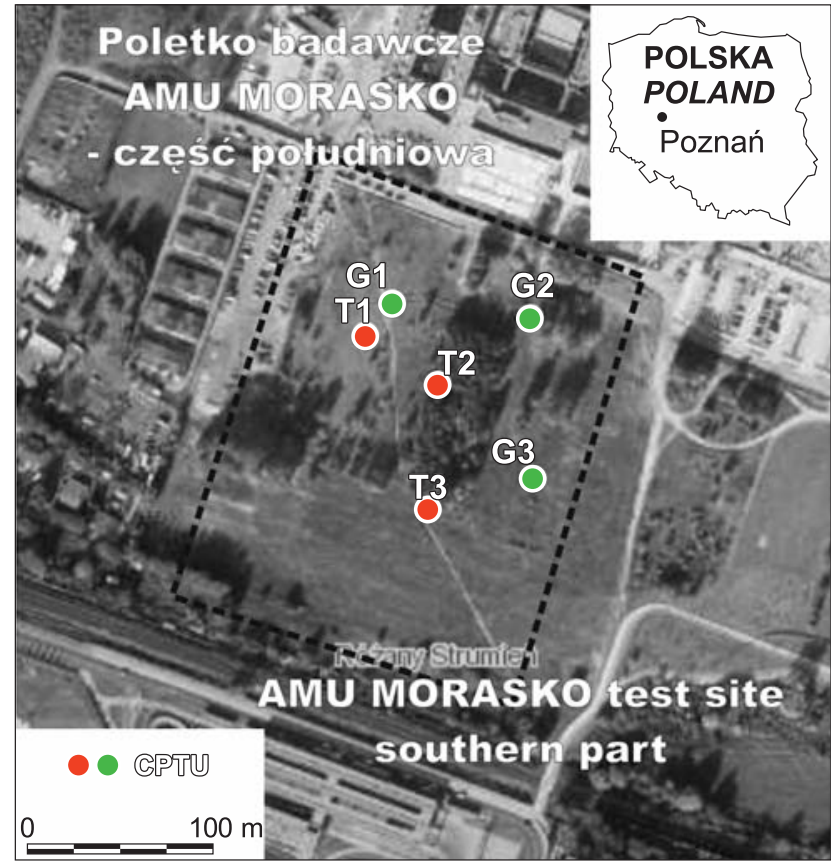

Ryc. 1. Lokalizacja testów CPTU, wykonanych sondami T i G, na poletku badawczym AMU Morasko

Fig. 1. Location of CPTU, performed using penetrometers $\mathrm{T}$ and $\mathrm{G}$, on the AMU Morasko test site

lodowcowa $\mathrm{z}$ wytopienia, wykształcona w postaci piasków gliniastych i glin piaszczystych, zawierająca ok. 10\% frakcji iłowej (Radaszewski, Stefaniak, 2017). Warstwa ta zalega na głębokości od ok. 3,5 do 15,5 m (Wierzbicki i in., 2018) i lokalnie jest ona rozdzielona przez piaszczyste przewarstwienia. Wyniki badań wytrzymałościowych pozwalają zaliczyć te grunty do przejściowych, m.in. na podstawie kryterium zależności warunków odpływu od prędkości zniszczenia (DeJong i in., 2013).

W analizowanym fragmencie profilu konsystencja gruntu, zawierającego ok. 4\% węglanu wapnia, jest plastyczna lub miękkoplastyczna i wynika ona z dużej porowatości gruntu oraz płytkiego występowania wody gruntowej (tab. 1). Z powodu małej zawartości frakcji iłowej badany grunt cechuje się niewielkim wskaźnikiem plastyczności.

Do badań wykorzystano wyniki 6 testów CPTU, wykonanych przez dwóch niezależnych operatorów posługujących się penetrometrami dwóch producentów (oznaczonych w niniejszej pracy jako G i T). Lokalizacja poszczególnych testów była losowa, co minimalizowało wpływ ewentualnego trendu zmian właściwości podłoża na wyniki analizy. Pole podstawy stożka penetrometru $G$ wynosiło $10 \mathrm{~cm}^{2}$, a penetrometru $\mathrm{T}-15 \mathrm{~cm}^{2}$. Obie końcówki pomiarowe umożliwiają rejestrację podstawowych parametrów sondowania $-q_{c}, f_{s}, u_{2}$ (patrz Lunne i in., 1997) - w odstępach punktów pomiaru co $1 \mathrm{~cm}$ głębokości. Urządzenia zostały przygotowane zgodnie ze standardami, w szczególności zastosowano nowe elementy cierne oraz odpowiednio odpowietrzony układ pomiarowy ciśnienia porowego. Badania wykonano od powierzchni terenu do głębokości 10 m (ryc. 2). Wyniki pomiarów przetworzono zgodnie z zasadami wskazanymi przez Lunne i in. (1997) oraz Robertson (2009), uzyskując dodatkowe parametry wykorzystane w analizie: $q_{t}$ (skorygowany opór stożka), $R_{f}$ (współczynnik

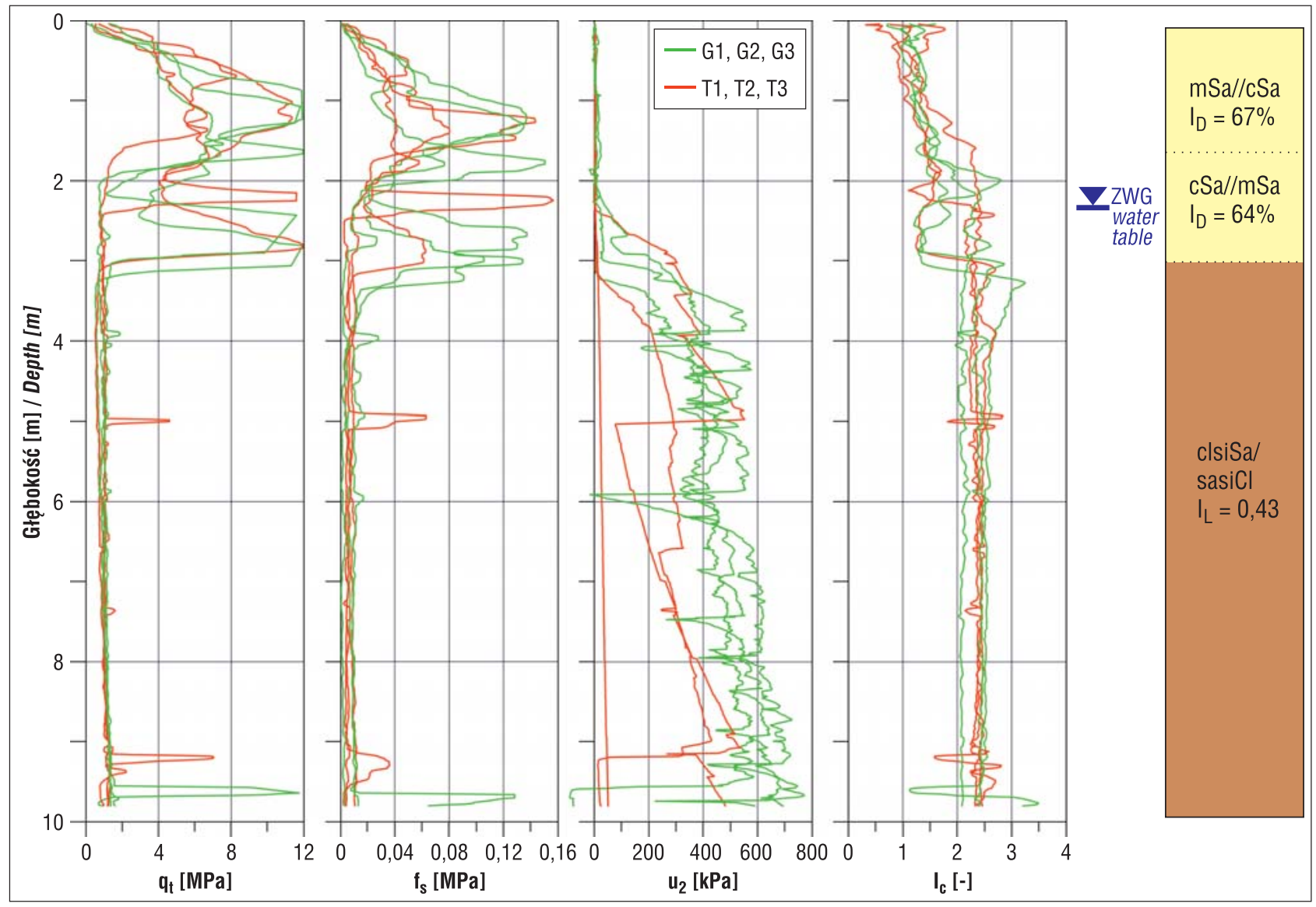

Ryc. 2. Zgeneralizowany profil osadów w podłożu poletka badawczego AMU Morasko i wyniki 6 analizowanych sondowań statycznych Fig. 2. Generalized soil profile of the AMU Morasko test site and results of six CPTUs 
Tab. 1. Podstawowe właściwości fizyczne analizowanego gruntu (wg Wierzbickiego i in., 2018)

Table 1. Basic physical parameters of the analyzed intermediate soils (after Wierzbicki et al., 2018)

\begin{tabular}{|l|c|c|c|c|c|c|}
\hline & $\begin{array}{c}\text { Wilgotność naturalna } \\
\text { Natural moisture } \\
{[\%]}\end{array}$ & $\begin{array}{c}\text { Granica plastyczności } \\
\text { Plasticity limit } \\
{[\%]}\end{array}$ & $\begin{array}{c}\text { Granica plynności } \\
\text { Liquidity limit } \\
\text { [\%] }\end{array}$ & $\begin{array}{c}\text { Wskaźnik plastyczności } \\
\text { Plasticity index } \\
{[\%]}\end{array}$ & $\begin{array}{c}\text { Stopień plastyczności } \\
\text { Liquidity index }\end{array}$ & $\begin{array}{c}\text { CaCO }_{3} \\
\text { [\%] }\end{array}$ \\
\hline $\begin{array}{l}\text { Przedział } \\
\text { Interval }\end{array}$ & $13,25 \div 17,35$ & $9,07 \div 12,67$ & $15,39 \div 23,9$ & $4,44 \div 10,96$ & $0,35 \div 0,75$ & $3 \div 5$ \\
\hline $\begin{array}{l}\text { Średnia } \\
\text { Average }\end{array}$ & 16,67 & 10,88 & 17,01 & 6,13 & 0,66 & - \\
\hline
\end{tabular}

tarcia), $Q_{t n}$ (znormalizowany opór stożka), $F_{r}$ (znormalizowany współczynnik tarcia) i $I_{c}$ (parametr zachowania gruntu). Na podstawie wstępnej analizy profilu osadów oraz rozpoznania budowy geologicznej poletka badawczego do dalszej analizy wybrano wyniki badań z przedziału głębokości 3,5-9,0 m, cechującego się wyraźną jednorodnością litologiczną. Niezależnie od danych geologicznych do takiego samego wniosku prowadzą obserwacje lokowania się wyników sondowań statycznych CPTU na diagramie gruntów Robertsona (2010) w strefie piasku pylastego i pyłu piaszczystego, na pograniczu z gruntami wrażliwymi niezależnie od zastosowanego penetrometru (ryc. 3), a także analiza grupowania się wartości $R_{f}$ i $I_{c}$.

\section{METODYKA ANALIZY JAKOŚCI POMIARÓW CPTU}

\section{Podstawy analizy}

Wartości parametrów uwzględnionych w analizie: skorygowanego oporu stożka $\left(q_{t}\right)$, tarcia na pobocznicy $\left(f_{s}\right)$ i wzbudzonego ciśnienia porowego $\left(u_{2}\right)$, bardzo często są uzależnione od stanu naprężenia podłoża. W analizowanym przypadku osadów normalnie konsolidowanych i o konsystencji plastycznej, zmierzone wartości $q_{t}, f_{s}$ i $u_{2}$ zostały odniesione do składowej pionowej geostatycznego stanu naprężenia $\sigma_{v 0}$ i ciśnienia hydrostatycznego $u_{0}$. Zmiany wartości mierzonych parametrów, następujące wraz z przyrostem naprężenia, zdefiniowano jako ich trend $\mathrm{z}$ głębokością. Zmienność parametrów CPTU w teście replikacyjnym można zatem zapisać jako składnik trendu $\xi(z)$ wraz z częściowo losowym składnikiem $\varepsilon(z)$ o średniej równej 0 i wariancji zależnej od $z$.

$$
x_{i k}(z)=\xi_{i k}(z)+\varepsilon_{i k}(z)
$$

gdzie:

$\xi_{i k}(z)$ - wartość rzeczywista parametru $\xi$ na głębokości z; $\varepsilon_{i k}(z)$ - losowy szum o zerowej średniej, zależny od z.

Jednocześnie odchylenia od trendu cechuje pewna korelacja przestrzenna, której analizę można przeprowadzić poprzez badanie funkcji autokorelacji $R(L)$, w której $L$ oznacza tzw. opóźnienie (Seber, 1989; Uzielli, 2008). Obliczenie funkcji autokorelacji jest uwarunkowane próbą danych $\mathrm{z}$ punktów równoodległych. W takim wypadku $R(L)$ zmienia się od 1 przy idealnej korelacji do 0 przy jej braku. Teoretycznie funkcja autokorelacji jest także równa jedności przy zerowym opóźnieniu $L[R(0)=1]$. Jednak w przypadku obecności szumu funkcja $R(L)$ przyjmuje wartości z przedziału 0-1, w zależności od wielkości rejestrowanego szumu. Ta właściwość funkcji jest wykorzystywana do ilościowego określenia udziału szumu w rejestrowanym pomiarze.

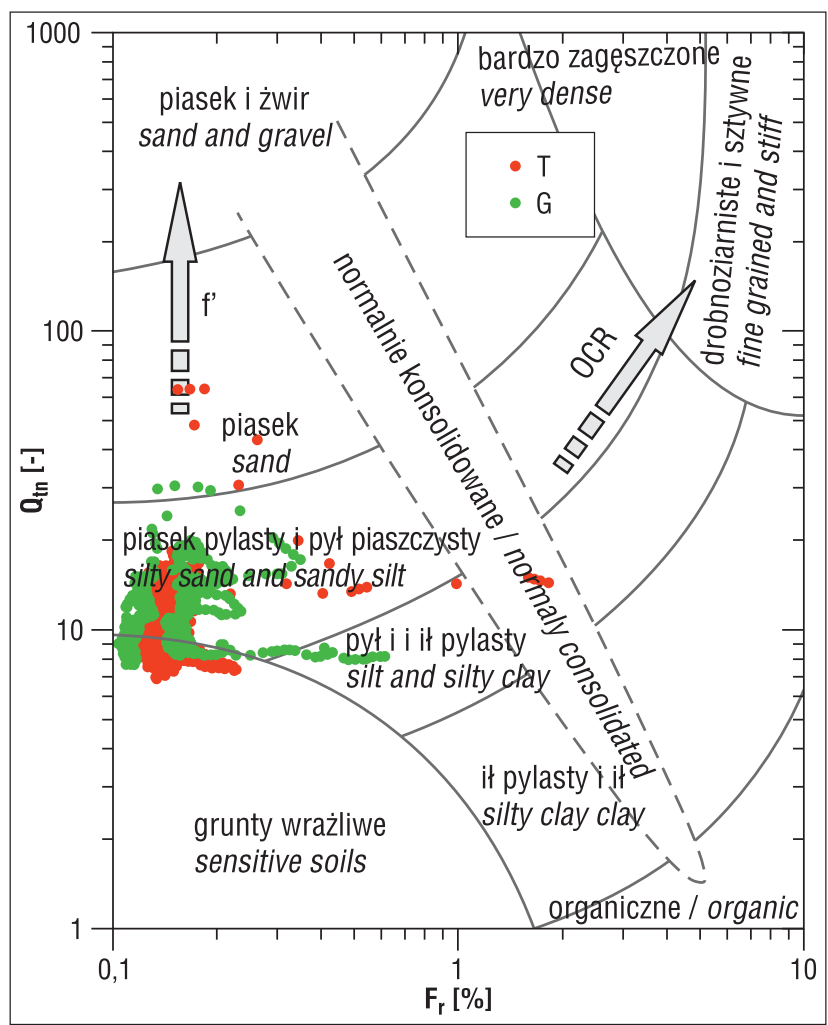

Ryc. 3. Rozmieszczenie wyników sondowań statycznych CPTU na diagramie gruntów Robertsona (2010), z uwzględnieniem rodzaju penetrometru - G i T

Fig. 3. Location of CPTU results on the Roberston's SBC (2010), with indication of two different penetrometers $-\mathrm{G}$ and $\mathrm{T}$

\section{Precyzja i dokładność}

Ze względu na brak precyzji pomiaru rzeczywista wartość parametru mierzonego w sondowaniu statycznym może różnić się od wartości mierzonych podczas testu replikacyjnego wykonywanego z użyciem różnych penetrometrów. Na skutek niedokładności pomiaru również średnia $\mathrm{z}$ poszczególnych powtórzeń badania $\mathrm{w}$ teście replikacyjnym może różnić się od wartości rzeczywistej. Wartość precyzji, w kontekście obserwowanego trendu zmian wartości parametru z głębokością, można zdefiniować jako:

$$
\operatorname{prec}=\operatorname{avg}\left(\operatorname{std}\left(f_{k}(z)\right)\right)
$$

gdzie:

$f_{k}$ - trend zmian danego parametru CPTU w $\mathrm{i}_{\text {tej }}$ lokalizacji badania.

Wartość precyzji jest więc określona prostą regułą - im większa zmienność tym mniejsza precyzja. 


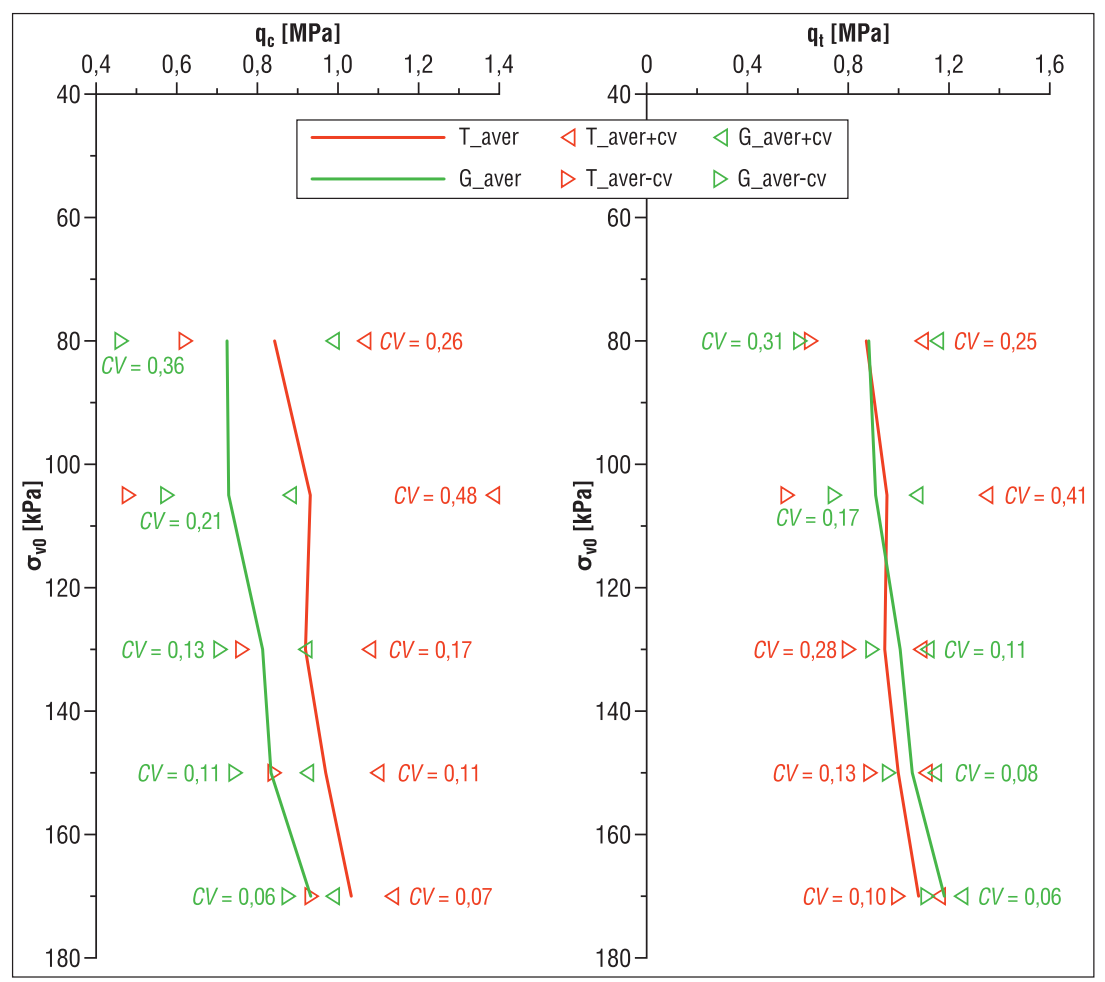

Ryc. 4. Zmiany średnich wartości oporu stożka i skorygowanego oporu stożka penetrometrów G i T oraz współczynniki ich zmienności

Fig. 4. Change in average cone resistance and corrected cone resistance for penetrometers $\mathrm{G}$ and $\mathrm{T}$, and the coefficient of variation

dalszych analizach wykorzystywano wartości skorygowanego oporu stożka $q_{t}$, w pierwszej kolejności określono wpływ zastosowanej korekty ciśnienia porowego na mierzone wartości oporu stożka $q_{c}$. W tym celu wartości $q_{c}$ i $q_{t}$ uśredniono w jednometrowych przedziałach głębokości - dla każdego z badań CPTU - oraz obliczono wartości współczynników ich zmienności $\left(c_{v}\right)$. Tym samym uzyskano

W celu zbadania precyzji pomiarów, dla wszystkich danych z pojedynczego testu CPTU określono trend liniowy jego parametrów, a następnie uśredniono trendy wszystkich testów wykonanych jednym penetrometrem. W ten sposób określono średni trend danego penetrometru oraz trendy górnego i dolnego przedziału dla obliczonej precyzji pomiaru.

\section{Szum}

W celu określenia szumu, rozumianego jako losowy składnik zmienności wartości określonego parametru, wszystkie dane w poszczególnych profilach CPTU poddano działaniu średniej ruchomej, co umożliwiło ograniczenie możliwości wpływu naturalnej zmienności cech gruntu. Następnie określono autokorelację obserwowanych różnic, dopasowując ją do przebiegu funkcji wykładniczej (Winter i in., 1999).

Poziom szumu określono zgodnie z równaniem [3].

$$
\text { szum }=\sqrt{1-\rho^{2}} \cdot \sigma
$$

gdzie:

$\sigma$ - odchylenie standardowe szumu;

$\rho$ - współczynnik autokorelacji.

\section{WYNIKI}

\section{Analiza trendu}

Zgodnie z założeniami przedstawionymi w rozdziale dotyczącym metodyki analizy jakości pomiarów CPTU, wyniki sondowań statycznych poddano analizie trendu rejestrowanych parametrów CPTU z wartością naprężenia pionowego $\sigma_{v 0}$. Wartość $\sigma_{v 0}$ obliczono na podstawie nominalnej głębokości pomiaru oraz ciężaru objętościowego gruntu (Radaszewski, Wierzbicki, 2019). Ponieważ w porównanie zmienności parametru zmierzonego i skorygowanego na różnych poziomach $\sigma_{v 0}$ (ryc. 4).

Następnie, zgodnie z koncepcją wyrażoną równaniami [1 i 2], wszystkie dane z poszczególnych sondowań dopasowano do trendu liniowego, który z kolei uśredniono dla poszczególnych rodzajów penetrometrów (ryc. 5).

\section{Precyzja}

Precyzję pomiaru, rozumianą jako stopień zgodności uzyskanych wyników, określono według równania [2], analizując odrębnie $q_{t}, f_{s}$ i $u_{2}$ dla każdego z penetrometrów. $\mathrm{Na}$ tej podstawie dla każdego ze średnich trendów wyznaczonych dla penetrometrów G i T (ryc. 5) obliczono precyzję (tab. 2). Uzupełnieniem analizy było wyznaczenie

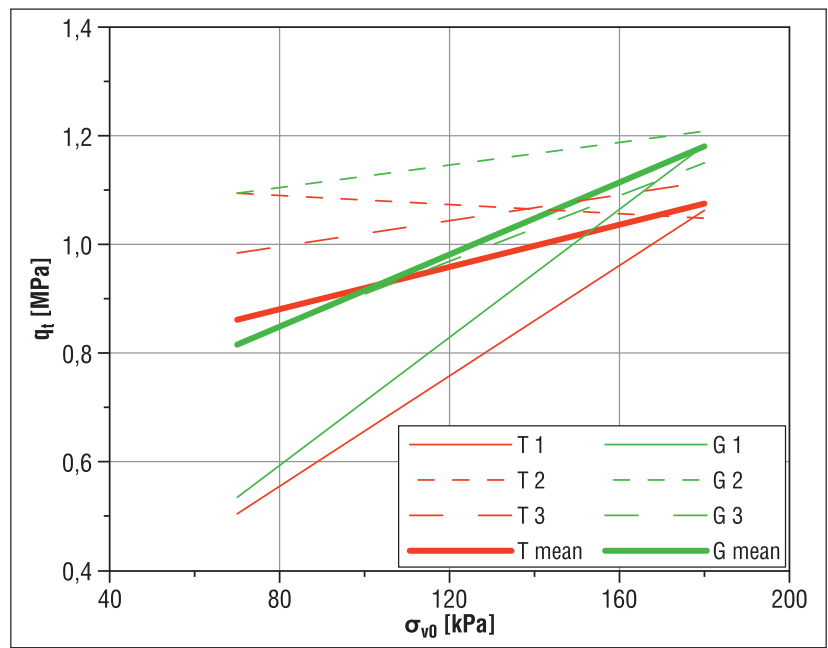

Ryc. 5. Wyznaczone trendy oporu stożka $q_{t}$ z głębokością dla poszczególnych badań oraz średni trend uzyskany dla penetrometrów G i T

Fig. 5. Functions of the cone resistance trend $q_{t}$ for individual tests and the mean trend for $\mathrm{G}$ and $\mathrm{T}$ penetrometers 


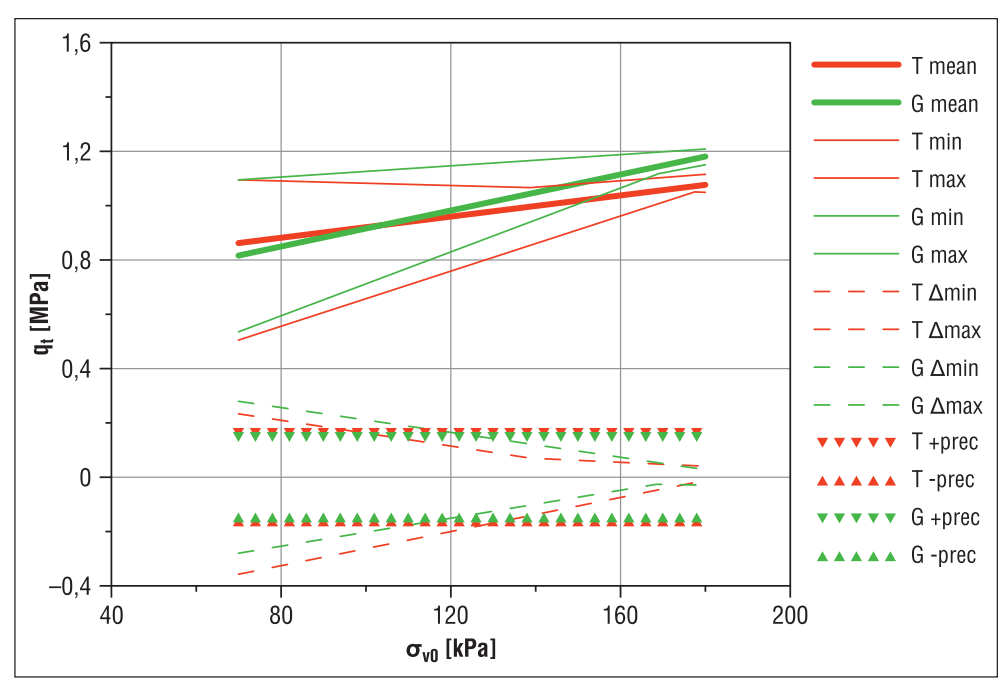

Ryc. 6. Średni, dolny $(\min )$ i górny $(\max )$ trend oporu stożka $\left(q_{t}\right)$ na tle różnic $\Delta \max =\max -$ śred., $\Delta \min =\min -$ śred. oraz górnej i dolnej obwiedni precyzji penetrometrów T i G

Fig. 6. Mean, lower ( $\min )$ and upper (max) trend envelope for the cone resistance $\left(q_{t}\right)$ on the background of the difference $\Delta \max =\max -$ mean, $\Delta \min =\min -$ mean, and the \pm precision envelopes for penetrometers $\mathrm{T}$ and $\mathrm{G}$

\section{Precyzja oceny wybranych parametrów geotechnicznych}

Wyniki analizy dokładności pomiarów prowadzonych podczas sondowania statycznego mogą być wykorzystane do oceny, jak precyzyjnie zostały wyliczone na ich podstawie parametry geotechniczne gruntu. W tym celu w analizowanym zakresie głębokości obliczono wartości modułu ściśliwości $(M)$ i wytrzymałości na ścinanie bez odpływu $\left(s_{u}\right)$. Do wyznaczenia $M$ wykorzystano formułę obliczeniową [4], zaproponowaną przez Młynarka i in. (2016). Wartości $s_{u}$ wyznaczono stosując równanie [5] i przyjmując wartość $N_{k t}=8$ (wg Radaszewskiego, Wierzbickiego, 2019).

$$
\begin{aligned}
& M=13,13\left(q_{t}-\sigma_{v 0}\right) \\
& s_{u}=\frac{\left(q_{t}-\sigma_{v 0}\right)}{N_{k t}}
\end{aligned}
$$

Tab. 2. Wartość precyzji penetrometrów T i G obliczona na podstawie funkcji liniowej $q_{t}, f_{s}, u_{2}$ i $R_{f}$ Table 2. Precision values penetrometers $\mathrm{T}$ and $\mathrm{G}$ based on linear fit for $q_{t}, f_{s}, u_{2}$ and $R_{f}$

\begin{tabular}{|l|c|c|c|c|c|}
\hline $\begin{array}{c}\text { Penetrometr } \\
\text { Penetrometer }\end{array}$ & $\begin{array}{c}\text { Glębokość } \\
\text { Depth } \\
{[\mathbf{m}]}\end{array}$ & $\begin{array}{c}\boldsymbol{q}_{t} \\
{[\mathbf{M P a}]}\end{array}$ & $\begin{array}{c}\boldsymbol{f}_{\text {s }} \\
{[\mathbf{M P a}]}\end{array}$ & $\begin{array}{c}\boldsymbol{u}_{2} \\
{[\mathbf{k P a}]}\end{array}$ & $\begin{array}{c}\boldsymbol{R}_{f} \\
{[\%]}\end{array}$ \\
\hline $\mathrm{T}$ & $3,5-9,0$ & 0,1629372 & 0,00253933 & 158,3698 & 0,1434668 \\
\hline $\mathrm{G}$ & $3,5-9,0$ & 0,1483123 & 0,00446313 & 53,5857 & 0,4057137 \\
\hline $\mathrm{T}$ & $3,5-4,5$ & 0,2573323 & 0,00246438 & 177,9597 & 0,1419473 \\
\hline $\mathrm{G}$ & $3,5-4,5$ & 0,2846258 & 0,00550103 & 85,3664 & 0,6604839 \\
\hline $\mathrm{T}$ & $8,0-9,0$ & 0,0510366 & 0,00303622 & 221,0517 & 0,2517365 \\
\hline $\mathrm{G}$ & $8,0-9,0$ & 0,0524091 & 0,00426425 & 58,8728 & 0,3593241 \\
\hline
\end{tabular}

Objaśnienia: $\boldsymbol{q}_{t}-$ skorygowany opór stożka; $\boldsymbol{f}_{\boldsymbol{s}}$ - tarcie na pobocznicy; $\boldsymbol{u}_{2}-$ wzbudzone ciśnienie porowe; $\boldsymbol{R}_{\boldsymbol{f}}-$ współczynnik tarcia Explanations: $\boldsymbol{q}_{t}-$ cone resistance; $\boldsymbol{f}_{\boldsymbol{s}}-$ sleeve friction; $\boldsymbol{u}_{2}$ - pore pressure; $\boldsymbol{R}_{\boldsymbol{f}}-$ friction coefficient

maksymalnej i minimalnej wartości danego parametru, wynikającej z trendów składowych trendu średniego. Tym samym uzyskano również wartość różnicy $\Delta$, między trendem średnim a wartością maksymalną lub minimalną (ryc. 6). Kierując się wyraźną zmiennością wartości $\Delta \max$ i $\Delta \min$, widoczną np. na ryc. 6, analizę precyzji postanowiono przeprowadzić także odrębnie dla początkowego i końcowego przedziału głębokości o długości $1 \mathrm{~m}$. W ten sposób otrzymano również wartości precyzji poszczególnych parametrów w przedziałach głębokości: $3,5-4,5$ oraz $8,0-9,0 \mathrm{~m}$ (tab. 2).

\section{Szum}

Analizę szumu przeprowadzono wzdłuż całego profilu badawczego, odrębnie dla każdego z sondowań CPTU. W takim ujęciu szum określał poziom fluktuacji mierzonego parametru podczas wykonywania pojedynczego badania. Wartości szumu, obliczone dla poszczególnych testów i parametrów, zestawiono w tab. 3 .
Tab. 3. Wartości szumu poszczególnych mierzonych parametrów, z wyszczególnieniem wartości maksymalnej dla danego typu penetrometru $\left(\mathrm{G}_{\max }, \mathrm{T}_{\max }\right)$

Table 3. Noise values for measured parameters with the highlighted maximum values of individual penetrometers $\left(\mathrm{G}_{\max }, \mathrm{T}_{\max }\right)$

\begin{tabular}{|l|c|c|c|}
\hline \multirow{2}{*}{$\begin{array}{l}\text { Penetrometr } \\
\text { Penetrometer }\end{array}$} & \multicolumn{3}{|c|}{ Szum / Noise } \\
\cline { 2 - 4 } & $\mathbf{q}_{\mathbf{t}}[\mathbf{M P a}]$ & $\mathbf{f}_{\mathbf{s}}[\mathbf{M P a}]$ & $\mathbf{u}_{\mathbf{2}}[\mathbf{k P a}]$ \\
\hline $\mathrm{G} 1$ & 0,000773 & 0,0000253 & 1,8281406 \\
\hline $\mathrm{G} 2$ & 0,006736 & 0,0000737 & 2,2707676 \\
\hline $\mathrm{G} 3$ & 0,002959 & 0,0000178 & 2,2707676 \\
\hline $\mathrm{G}_{\max }$ & 0,006736 & 0,0000737 & 2,2707676 \\
\hline $\mathrm{T} 1$ & 0,001609 & 0,0000100 & 0,3766164 \\
\hline $\mathrm{T} 2$ & 0,034657 & 0,0002247 & 0,8164286 \\
\hline $\mathrm{T} 3$ & 0,001419 & 0,0002247 & 0,0095140 \\
\hline $\mathrm{T}_{\max }$ & 0,034657 & 0,0002247 & 0,8164286 \\
\hline
\end{tabular}

Objaśnienia skrótów umieszczono pod tabelą 2

For explanations of abbreviations see the legend to Table 2 
Obliczenia przeprowadzono odrębnie dla każdego z penetrometrów, przyjmując za $q_{t}$ wartość średniego trendu tego parametru. Dodatkowo wyznaczono przedziały maksymalnej i minimalnej wartości analizowanego parametru, dodając lub odejmując wartość precyzji i szumu pomiaru $q_{t}$.

\section{DYSKUSJA}

Na podstawie wyników opisanej analizy można stwierdzić, że jakiekolwiek różnice w uzyskanych wyliczeniach nie wynikają z wykonywania badań konkretnym penetrometrem. Niezależnie od przedziału głębokości, w jakim prowadzono analizę, uzyskano niemal identyczne trendy skorygowanego oporu stożka $q_{t}$ oraz bardzo zbliżoną precyzję pomiaru (ryc. 7). Warto też zauważyć, że precyzja pomiaru bardzo wyraźnie wzrasta wraz z głębokością, w interwale 8,0-9,0 m osiągając ok. 0,05 MPa.

Do nieco odmiennych wniosków prowadzi analiza wartości tarcia na pobocznicy $\left(f_{s}\right)$. Co prawda trendy tego parametru, wyliczone na podstawie wyników pomiarów wykonanych za pomocą obu penetrometrów, są podobne, jednak w precyzji pomiaru zaznacza się wyraźna różnica (szczególnie w płytszym interwale profilu) na korzyść penetrometru T (ryc. 8). Wyraźne różnice pomiędzy wynikami

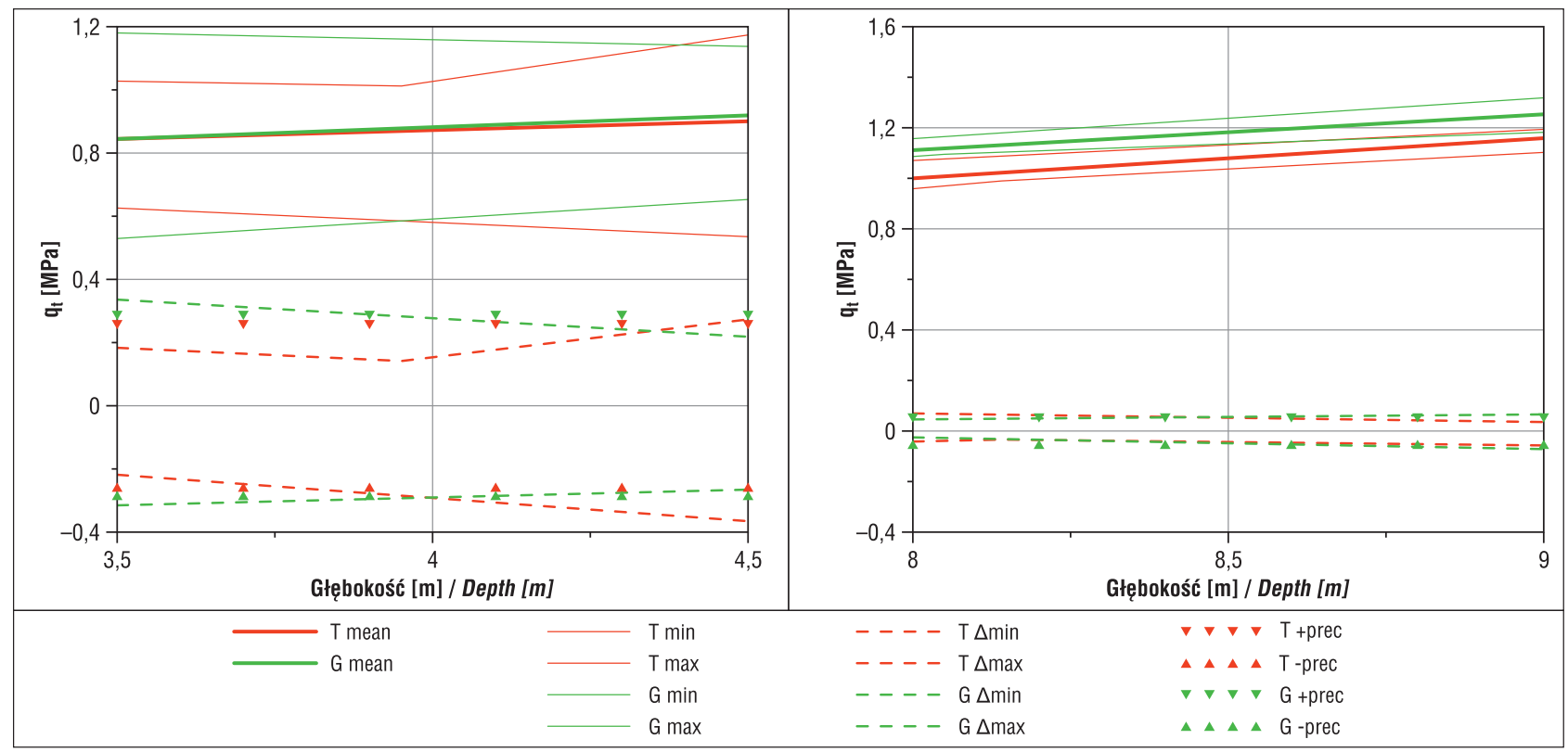

Ryc. 7. Średni, dolny (min) i górny $(\max )$ trend oporu stożka $\left(q_{t}\right)$ na tle różnic $\Delta \max =\max -$ śred., $\Delta \min =\min -$ śred. oraz górnej i dolnej obwiedni precyzji penetrometrów T i G w dwóch różnych przedziałach głębokości

Fig. 7. Mean, lower $(\mathrm{min})$ and upper $(\max )$ trend envelope for the cone resistance $\left(q_{t}\right)$ on the background of the difference $\Delta \max =\max -\operatorname{mean}$, $\Delta \min =\min -$ mean, and the \pm precision envelopes for penetrometers $\mathrm{T}$ and $\mathrm{G}$ and two depth intervals

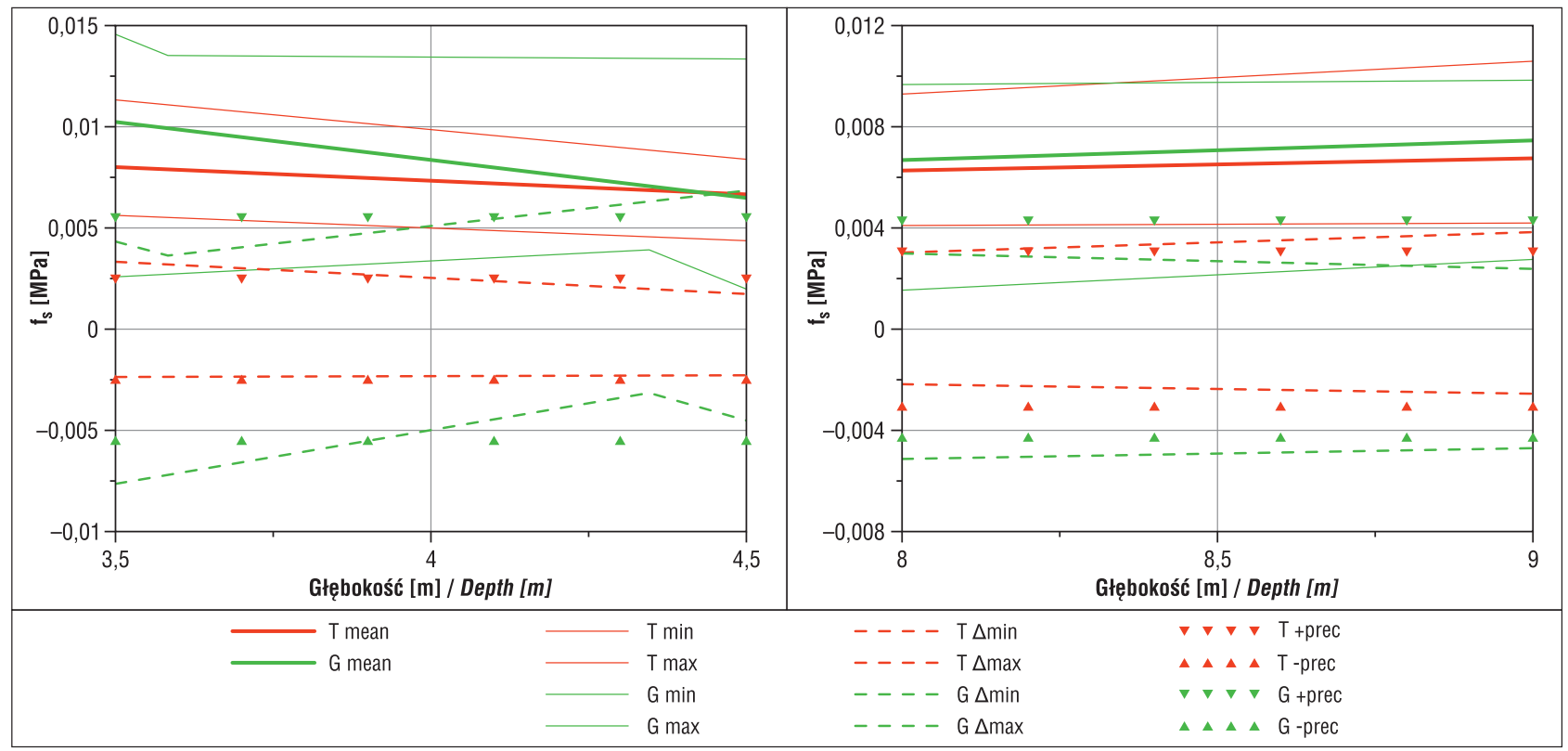

Ryc. 8. Średni, dolny $(\min )$ i górny $(\max )$ trend tarcia na pobocznicy $\left(f_{s}\right)$ na tle różnic $\Delta \max =\max -$ śred., $\Delta \min =\min -$ śred. oraz górnej i dolnej obwiedni precyzji pomiarów z zastosowaniem penetrometrów T i G w dwóch różnych przedziałach głębokości

Fig. 8. Mean, lower (min) and upper (max) trend envelope for the sleeve friction $\left(f_{s}\right)$ on the background of the difference $\Delta \max =\max -\operatorname{mean}$, $\Delta \min =\min -$ mean, and the \pm precision envelopes for penetrometers $\mathrm{T}$ and $\mathrm{G}$ and two depth intervals 


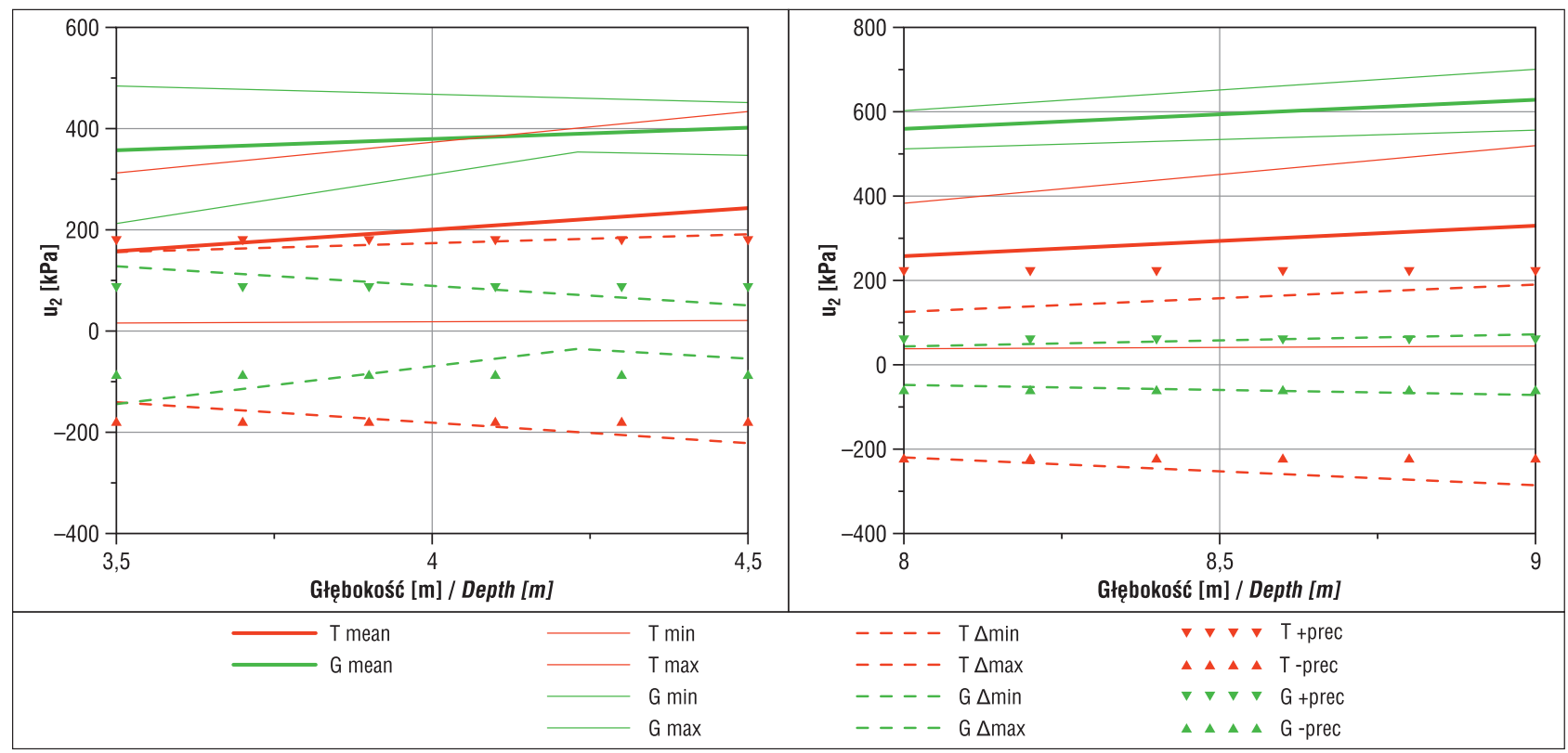

Ryc. 9. Średni, dolny $(\min )$ i górny $(\max )$ trend ciśnienia porowego $\left(u_{2}\right)$ na tle różnic $\Delta \max =\max -$ śred., $\Delta \min =\min -$ śred. oraz górnej i dolnej obwiedni precyzji pomiarów za pomocą penetrometrów T i G w dwóch różnych przedziałach głębokości

Fig. 9. Mean, lower $(\min )$ and upper $(\max )$ trend envelope for the pore pressure $\left(u_{2}\right)$ on the background of the difference $\Delta \max =\max -\operatorname{mean}$, $\Delta$ min $=$ min - mean, and the \pm precision envelopes for penetrometers $\mathrm{T}$ and $\mathrm{G}$, and two depth intervals

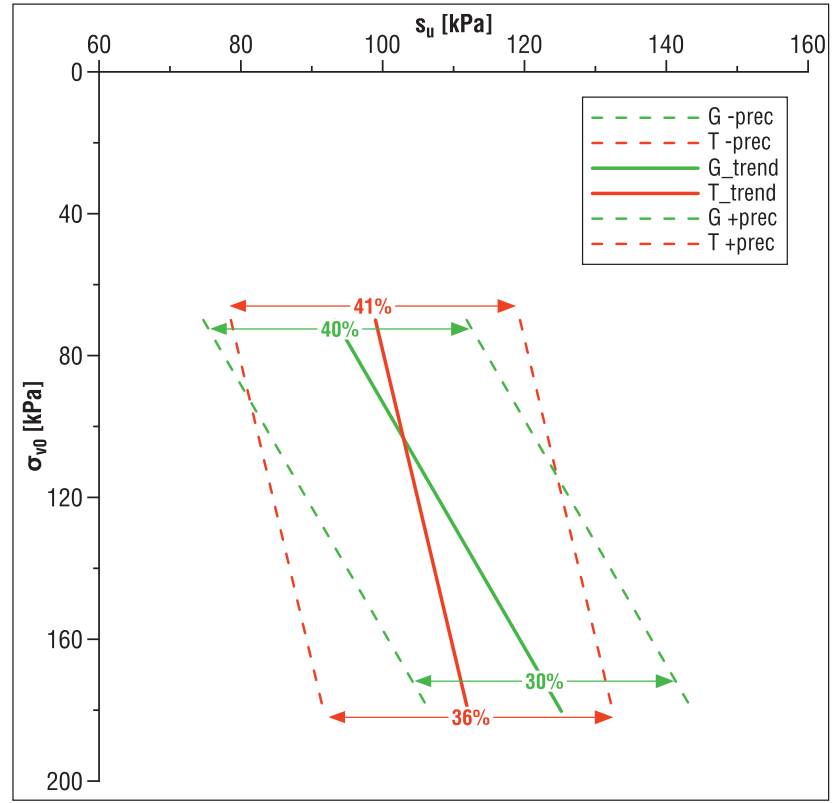

Ryc. 10. Średni trend wytrzymałości na ścinanie bez odpływu $\left(s_{u}\right)$ na tle zakresu wynikającego z oceny jakości pomiaru

Fig. 10. Mean trend envelope of undrained shear strength $\left(s_{u}\right)$ and range of precision area for $s_{u}$

pomiarów wykonywanych penetrometrami T i G można natomiast zaobserwować w przypadku trendu i precyzji pomiaru ciśnienia porowego $\left(u_{2}\right)$. Wartości trendu wyliczone dla tych dwóch penetrometrów różnią się o 100\%. Przy czym penetrometr T wykazuje bardzo małą precyzję, której wartość jest niemal tożsama z wartościami trendu (ryc. 9).

Wielkości szumu są na bardzo niskim poziomie, jednak różnią się niekiedy o rząd wielkości. Dyskusyjność wykorzystania szumu jako parametru w analizie jakości wykazuje przede wszystkim pomiar ciśnienia porowego $\left(u_{2}\right)$, którego wielkość, mierzona penetrometrem T, zmienia się niemal liniowo (niski szum), natomiast w przypadku pene-

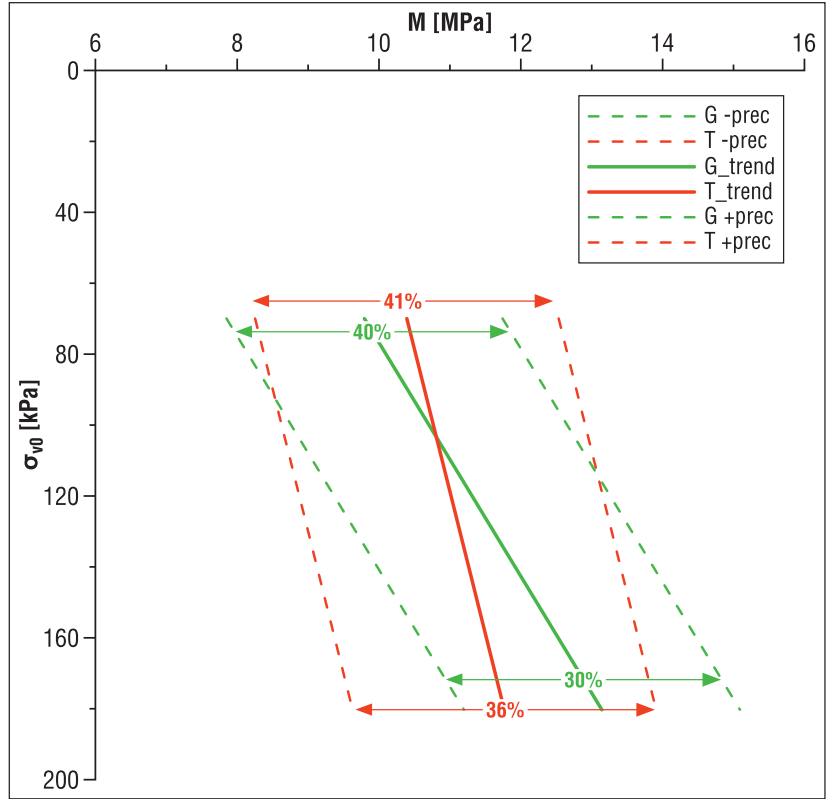

Ryc. 11. Średni trend modułu ściśliwości $(M)$ na tle zakresu wynikającego z oceny jakości pomiaru

Fig. 11. Mean trend envelope of constrained modulus $(M)$ and range of precision area for $M$

trometru G wykazuje dużo większą precyzję pomiaru, co jednocześnie skutkuje większą wielkością szumu.

Analiza zmienności parametrów geotechnicznych badanego gruntu wskazuje, że niewielkie różnice w wynikach pomiarów tych parametrów są uzależnione od rodzaju penetrometru użytego do badań i od zmian stanu naprężenia gruntu w profilu (ryc. 10 i 11). Biorąc pod uwagę wartość trendu, różnice te nie przekraczają 10\%. Bardziej znaczące są natomiast różnice wynikające z niedostatecznej precyzji pomiaru. Wyniki pomiarów wytrzymałości na ścinanie bez odpływu $\left(s_{u}\right)$ wskazują, że oba penetrometry cechują się tendencją do wzrostu precyzji pomiaru wraz z głębokościa, 
natomiast $\mathrm{w}$ przypadku modułu ściśliwości $(M)$ tendencja ta nie zaznacza się, ponieważ wyniki pomiarów wykonanych jednym $z$ analizowanych penetrometrów świadczą wręcz o pogorszeniu się precyzji pomiaru wraz ze wzrostem głębokości wykonywania pomiaru. Należy przypomnieć, że pozostałe wyniki badań wskazują na zdecydowany wzrost rzeczywistej precyzji pomiaru wraz ze wzrostem głębokości (tab. 2).

\section{PODSUMOWANIE I WNIOSKI}

Na podstawie wyników badań można stwierdzić, że w gruntach przejściowych problem precyzji pomiarów wykonywanych in situ jest szczególnie silnie eksponowany. Zróżnicowane poziomy precyzji i trendu parametrów geotechnicznych wyznaczanych na podstawie pomiarów wykonanych za pomocą różnych penetrometrów i na różnych głębokościach mogą prowadzić do istotnych różnic w ocenie właściwości mechanicznych podłoża. Stwierdzenie, na ile zaobserwowane różnice są statystycznie istotne, wymaga jednak prowadzenia dalszych badań z wykorzystaniem większej liczby sondowań CPTU. Z tego względu opisane badania należy traktować jako pilotażowe, wymagające w późniejszym czasie uzupełnienia liczby testów CPTU do 9 badań każdym z urządzeń, co umożliwi bardziej złożoną i wiarygodną analizę statystyczną różnic. Pomimo ograniczonej liczby pomiarów wykorzystanych w opisanych badaniach ich wyniki wskazują na zasadność wykonywania kalibracyjnych badań porównawczych penetrometrów z wynikami badań laboratoryjnych. Jednocześnie analiza geotechniczna podłoża prowadzona z wykorzystaniem badań sondowania statycznego powinna zawierać ocenę precyzji tej metody, prowadzoną np. w wybranych warstwach jednorodnych. Taka własna kalibracja metody jest szczególnie istotna $\mathrm{w}$ przypadku realizacji dużych projektów, w których wykorzystuje się wiele penetrometrów, nieraz różnych producentów.

\section{LITERATURA}

DEJONG J.T., JAEGER R.A., BOULANGER R.W., RANDOLPH M., WAHL D. A. J. 2013 - Variable penetration rate cone testing for charac- terization of intermediate soils. [W:] Coutinho R.Q., Mayne P.W. (eds.), Geotechnical and Geophysical Site Characterization 4 (Proceedings ISC-4: the fourth international conference on site characterization). CRC Press: $25-42$.

ISO 2012 - Geotechnical investigation and testing Field testing - Part 1: Electrical cone and piezocone penetration test (ISO 22476-1).

ISSMGE 1999 - Test Procedures for Cone Penetration (CPT) and Cone Penetration with Pore Pressure (CPTU). International Society for Soil Mechanics and Geotechnical Engineering Technical Committee TC-16. LACASSE S., NADIM F. 1994 - Reliability issues and future challenges in geotechnical engineering for offshore structures, Cambridge Mass.

LUMB P. 1974 - Applications of Statistics in Soil Mechanics. [W:] Lee J. K. (red.), Soil Mechanics-New Horizons. Newness-Batterworth, London. LUNNE T., LONG M., FORSBERG C.F. 2003 - Characterisation and engineering properties of Onsoy clay. [W:] Characterisation and engineering properies of natural soils. A A Balkema, British Library Conference Proceedings: 395-428.

LUNNE T., ROBERTSON P.K., POWELL J.J.M. 1997 - Cone penetration testing in geotechnical practice. Taylor \& Francis, London.

MLYNAREK Z. 2010 - Quality of in situ and laboratory tests contribution to risk management. $14^{\text {th }}$ Danube-European Conference on Geotechnical Engineering, Bratislava.

MLYNAREK Z., WIERZBICKI J., LUNNE T. 2016 - On the influence of overconsolidation effect on the compressibility assessment of subsoil by means of CPTU and DMT. Annals of Warsaw University of Life Sciences - SGGW Land Reclamation, 48 (3): 189-200.

MŁYNAREK Z., WOŁYŃSKI W., KROLL M. 2002 - Statistical evaluation of differences between the CPTU parameters obtained from tests with various penetrometers. Norwegian Geotechnical Institute.

RADASZEWSKI R., STEFANIAK K. 2017 - Problem wyznaczania wytrzymałości na ścinanie gruntów przejściowych. Prz. Geol., 65 (10/2): 864-872.

RADASZEWSKI R., WIERZBICKI J. 2019 - Characterization and engineering properties of AMU Morasko soft clay. AIMS Geosc., 5 (2): 235-264. ROBERTSON P.K. 2009 - Interpretation of cone penetration tests - a unified approach. Canadian Geotech. J., 46: 1337-1355.

ROBERTSON P.K. 2010 - Estimating in situ soil permeability from CPT $\& \mathrm{CPTu} .2^{\text {nd }}$ International Symposium on Cone Penetration Testing, Huntington Beach, CA, USA.

SEBER G.A.F. 1989 - Mulitcariate observations. John Wiley\&Sons, New York.

STANKOWSKI W. 2008 - Morasko Meteorite. A curiosity of the Poznań region. Wyd. Nauk. UAM Poznań, Poland.

UZIELLI M. 2008 - Statistical analysis of geotechnical data. [W:] Huang A.B., Mayne P.W. (red.), Geotechnical and Geophyical Site Characterization. Leiden, Taylor \& Francis: 173-193.

WIERZBICKI J., RADASZEWSKI R., WALIŃSKI M. 2018 - The variability of CPTU results on the AMU-Morasko soft clay test site. [W:] Hicks M.A., Pisano F., Peuchen J. (red.). Cone Penetration Testing 2018. London, Taylor and Francis Group.: 703-708.

WINTER B.J., BROWN D.R., MICHELS J.K.M. 1999 - Statistical principals in experimental design. Mc Grow-Hill, New York. 